\title{
Conditioning factors for the development of the self-care competence in the person with a tracheostomy
}

Fatores condicionadores do desenvolvimento da competência de autocuidado na pessoa com ostomia de ventilação

Factores condicionantes del desarrollo de la competencia de autocuidado en la persona con ostomía de ventilación

Sílvia Maria Moreira Queirós*; Célia Samarina Vilaça de Brito Santos**; Maria Alice Correia de Brito***; Igor Emanuel Soares Pinto****

\begin{abstract}
Background: The development of the self-care competence in the person with a stoma promotes a healthy transition to a life with a stoma. Studies suggest the existence of factors conditioning the development of the ostomy self-care competence. Objectives: To identify the conditioning factors for the development of the self-care competence in the person with a tracheostomy.

Methodology: A quantitative, descriptive, and cross-sectional study was conducted in a nonprobability sample composed of 80 participants. Data were collected using the "Assessment Form of the Self-Care Competence in the Person with a Tracheostomy.

Results: The conditioning factors for the development of the tracheostomy self-care competence were: being a man, having low schooling, having had an emergency surgery, having a temporary ostomy, and having a caregiver. The postoperative period proved to be a facilitating factor.

Conclusion: The recognition of the existence of factors conditioning the development of the tracheostomy self-care competence allows nurses to identify conditions of vulnerability in their patients and adapt their interventions with a view to enhancing their autonomy.
\end{abstract}

Keywords: self-care; ostomy; tracheostomy; nursing

\section{Resumo}

Enquadramento: $\mathrm{O}$ desenvolvimento da competência no autocuidado à ostomia é impulsionador de uma transição saudável para a vida com o estoma. Estudos sugerem a existência de fatores condicionadores do desenvolvimento da competência no autocuidado à ostomia.

Objetivos: Identificar os fatores condicionadores do desenvolvimento da competência de autocuidado na pessoa com ostomia de ventilação.

Metodologia: Estudo quantitativo, descritivo e transversal. Técnica de amostragem não probabilística, com 80 participantes. O instrumento de colheita de dados foi o Formulário de Avaliaçáo da Competência de Autocuidado na Pessoa com Ostomia de Ventilação.

Resultados: Ser do sexo masculino, ter baixa escolaridade, ter realizado cirurgia de urgência, ter uma ostomia temporária e ter um cuidador, constituem-se como fatores inibidores do desenvolvimento da competência de autocuidado à ostomia de ventilação. O tempo pós-operatório revelou-se como fator facilitador.

Conclusáo: $\mathrm{O}$ reconhecimento da existência de fatores condicionadores do desenvolvimento da competência no autocuidado à ostomia de ventilação permite ao enfermeiro identificar condiçóes de vulnerabilidade nos seus clientes e adequar as intervençôes de forma a potenciar a autonomia.

Palavras-chave: autocuidado; ostomia; traqueostomia; enfermagem

*MSc., RN, Centro Hospitalar S. João E.P.E., 4200-319, Porto, Portugal [silvia. queiros86@ gmail.com]. Contribution to the article: literature search; data collection; statistical treatment and evaluation, data analysis and discussion; article writing. Address for correspondence: Rua 32, $\mathrm{n}^{\circ} 900,3^{\circ}$ direito, 4500-319, Espinho, Portugal.

**Ph.D. Psychology, Coordinating Professor, Escola Superior do Porto, 4200-072, Porto, Portugal [celiasantos@esenf.pt]. Contribution to the article: statistical treatment and evaluation; data analysis and discussion; article writing.

***:Ph.D., Nursing. Adjunct Professor, Escola Superior do Porto, 4200-072, Porto, Portugal [alice@esenf.pt]. Contribution to the article: data analysis and discussion; article writing. ****MSc., Ph.D. student, Nursing, Universidade Católica Portuguesa, 4202-401, Porto, Portugal [isp.igor@gmail.com]. Contribution to the article: discussion; article writing.

\section{Resumen}

Marco contextual: El desarrollo de la competencia en el autocuidado a la ostomía impulsa una transición sana hacia la vida con un estoma. Los estudios sugieren que existen factores que condicionan el desarrollo de la competencia en el autocuidado a la ostomía.

Objetivos: Identificar los factores que condicionan el desarrollo de la competencia de autocuidado en la persona con ostomía de ventilación.

Metodología: Estudio cuantitativo, descriptivo y transversal. Técnica de muestreo no probabilística, con 80 participantes. El instrumento de recogida de datos fue el Formulario de Evaluación de la Competencia de Autocuidado en la Persona con Ostomía de Ventilación.

Resultados: Ser del sexo masculino, tener un bajo nivel de escolaridad, haber sido sometido a una cirugía de urgencia, tener una ostomía temporal y tener un cuidador son factores inhibidores del desarrollo de la competencia de autocuidado a la ostomía de ventilación. El tiempo posoperatorio fue un factor facilitador.

Conclusión: El reconocimiento de la existencia de factores que condicionan el desarrollo de la competencia en el autocuidado a la ostomía de ventilación permite al enfermero identificar condiciones de vulnerabilidad en sus pacientes y adecuar las intervenciones para potenciar la autonomía.

Palabras clave: autocuidado; estomía; traqueostomía; enfermería

Received for publication: 20.02.17

Accepted for publication: 08.05 .17 


\section{Introduction}

A tracheostomy is a critical event that brings about significant changes in a person's life, particularly in breathing, communication, swallowing, self-image, and self-care.

The acquisition of ostomy self-care competence is considered as one of the main drivers of transition to life with a stoma (O'Connor, 2005; Recalla et al., 2013; Mota et al., 2015). Understanding the factors that influence the development of tracheostomy self-care competence is essential to better understand the process of acquiring mastery in ostomy care and, at the same time, identify cases of greater vulnerability in ostomy adaptation. Thus, the objective of this study was to identify factors conditioning the development of the self-care competence in the person with a tracheostomy.

\section{Background}

The number of tracheostomies is increasing (Parker et al., 2007), particularly in patients admitted to intensive care units, with the primary purpose of facilitating mechanical ventilation. Nevertheless, the increasing incidence of head-neck cancer also contributes to the steady increase in the number of people with a tracheostomy (Maasland, Brandt, Kremer, Goldbohm, \& Schouten, 2014). As a result, there are increasingly more people with tracheostomies, not only in the hospital environment but also in the community, which is why the person's empowerment for living with a tracheostomy is an increasingly important focus of nurses' attention.

Despite its complexity and multidimensionality, the development of the ostomy self-care competence is described in the literature as one of the key drivers of a healthy transition. According to Orem (1995), self-care is a set of activities that the individual performs in order to maintain, restore, or improve their health, life, and general well-being. Thus, ostomy self-care focuses on the performance of activities inherent to caring for the stoma. Studies conducted on this topic (Mota et al., 2015; Lim, Chan, \& He, 2015) suggest the existence of conditioning, facilitating, or inhibiting factors for the development of the ostomy self-care competence, and, therefore, for the adaptation to associated experiences. Literature refers to sociodemographic factors such as age, gender, level of education, socio-economic status, marital status, and family and social support as potential conditioning factors for stoma adaptation, and, consequently, for autonomy in ostomy care (Brown \& Randle, 2005). Liu et al. (2016) suggest that ostomized women reveal a greater and better social interaction after the surgery, which leads to better stoma acceptance and perceived quality of life. On the other hand, a low level of education is associated with reduced ability to interact, seek professional help, and question and critically analyze health care (Bellato, Pereira, Maruyama, \& Oliveira, 2006). Factors related to a high socio-economic status, being married, and being professionally active are also referred to as leading to a better perception of post-ostomy quality of life (Pereira, Cesarino, Martins, Pinto, \& Netinho, 2012; Liu et al., 2016), self-efficacy, and self-care autonomy. Both the family and the support groups are also referred to as empowering patients to regain their self-care autonomy, redefine their identity, increase their self-esteem, and even promote their social reintegration (Mota et al., 2015).

Clinical factors such as the medical diagnosis, preoperative symptoms, time elapsed since surgery, and postoperative complications were also mentioned in the literature (Brown \& Randle, 2005; Registered Nurses' Association of Ontario [RNAO], 2009). Among these factors, literature refers to time elapsed since surgery as the most common facilitating factor for acceptance, adaptation and development of ostomy self-care (Bellato et al., 2006; Lim et al., 2015; Mota et al., 2016), as well as the duration of the ostomy, in which patients with a permanent ostomy revealed higher levels of autonomy and quality of life (Recalla et al., 2013; Campillo Martínez, 2015).

With regard to the health monitoring factors, the preoperative information is described as a variable that can enhance the adaptation to the ostomy and, consequently, the development of self-care competence (Walker \& Lachman, 2013; Mota et al., 2016).

Although several studies mention conditioning factors for the development of the ostomy selfcare competence and adaptation to the stoma, few studies focus on the target population of 
this study: patients with a traqueostomy. Given their influence in the transition process and development of the ostomy self-care competence, it is important to identify and understand these different variables for nurses' therapeutic interventions to be successful.

\section{Research Question}

What are the conditioning factors for the development of the self-care competence in the person with a tracheostomy?

\section{Methodology}

The research consisted of a quantitative, descriptive, and cross-sectional study. Data were collected in the postoperative period, both in hospitalization (immediate postoperative period) or in the community (after clinical discharge), using the Assessment Form of the Self-Care Competence in the Person with a Tracheostomy (Queirós, Santos, Brito, \& Pinto, 2015), which was designed within the scope of a Master's thesis in the Nursing School of Porto. The form consists of two parts: the first part consists of the participants' characterization through sociodemographic variables (such as age, marital status, level of education, profession, and professional status), clinical variables (clinical diagnosis, type of surgery, type of ostomy, time elapsed since ostomy), health monitoring variables (preoperative nursing consultation, prior contact with ostomized patients), and other variables, such as the existence of informal caregivers; the second part consists of the assessment of the tracheostomy self-care competence in its six areas: (A) Knowledge; (B) Self-monitoring; (C) Interpretation; (D) Decision-making; (E) Execution; and (F) Negotiation and Use of Health Resources. With regard to the Knowledge of tracheostomy self-care (A), the outcome indicators reflect the patient's understanding of the tracheostomy and associated care. As for Self-monitoring (B), the outcome indicators refer to the patient's ability to observe the tracheostomy and its characteristics. With regard to Interpretation (C), the outcome indicators are intended to assess the patient's ability to analyze and assign meanings to the changes associated with the tracheostomy. The dimension Decision-making (D) aims to assess the patient's ability to make decisions concerning tracheostomy care. The dimension Execution (E) assesses the patient's instrumental ability to perform the procedures inherent to tracheostomy care. The final domain to be assessed is Negotiation and Use of Health Resources (F) and its outcome indicators relate to the patient's ability to negotiate and use the resources available to support the ostomized patient.

The domains under study are scored on a Likert scale, ranging from 1 to 5 , in which the higher the score, the higher the competence. Thus, the categories are scored as follows: 1 - does not demonstrate, 2, 3, or 4 - partly demonstrates, 5 - fully demonstrates, 0 - does not apply. The assignment of a score between 2 and 4 varied according to the nurse's evaluation and was related to the number of criteria demonstrated within each indicator of the areas of competence (Queirós et al., 2015).

The main variable of the study was tracheostomy self-care competence and the secondary variables were the following: the set of sociodemographic variables (gender, age, level of education, professional status), clinical variables (time elapsed since surgery, medical diagnosis, type of surgery, type of ostomy based on duration), health monitoring variables (contact with ostomized patients before the surgery, and preoperative nursing consultations), and other variables, such as the existence of informal caregivers.

The criteria for inclusion in the sample were: being aged 18 years or over, having a tracheostomy (temporary or permanent), and agreeing to voluntarily participate in the study. The exclusion criteria were: being totally dependent on tracheostomy self-care and not having the cognitive ability to acquire this competence. This criterion was assessed, when necessary, through the application of the Mini Mental State Examination (MMSE) scale, which was validated and adapted to the Portuguese population (Guerreiro et al., 1994).

A nonprobability convenience sample was used. The sample was composed of 80 people who met the inclusion criteria and were followed-up in postoperative outpatient consultations or during hospitalization, in two hospitals in the Northern region (Table 1). 
Table 1

Characterization of the study sample $(n=80)$

\begin{tabular}{|c|c|c|}
\hline Variables & $n$ & $\%$ \\
\hline \multicolumn{3}{|l|}{ Age } \\
\hline $39-60$ & 40 & 50.00 \\
\hline $61-80$ & 39 & 48.75 \\
\hline$>80$ & 1 & 1.25 \\
\hline \multicolumn{3}{|l|}{ Gender } \\
\hline Female & 4 & 5.00 \\
\hline Male & 76 & 95.00 \\
\hline \multicolumn{3}{|l|}{ Level of Education } \\
\hline No education but knows how to read/write & 1 & 1.25 \\
\hline Up to $4^{\text {th }}$ grade & 47 & 58.75 \\
\hline Between $5^{\text {th }}$ and $12^{\text {th }}$ grade & 27 & 33.75 \\
\hline More than $12^{\text {th }}$ grade & 5 & 6.25 \\
\hline \multicolumn{3}{|l|}{ Professional Status } \\
\hline Retired, on medical leave, or disabled & 70 & 87.50 \\
\hline Unemployed & 9 & 11.25 \\
\hline Employed & 1 & 1.25 \\
\hline \multicolumn{3}{|l|}{ Time elapsed since ostomy } \\
\hline Up to 1 month & 22 & 27.50 \\
\hline More than 1 month & 58 & 72.50 \\
\hline \multicolumn{3}{|l|}{ Duration of ostomy } \\
\hline Temporary & 8 & 10.00 \\
\hline Permanent & 63 & 78.75 \\
\hline Does not know & 9 & 11.25 \\
\hline \multicolumn{3}{|l|}{ Ostomy-related surgery } \\
\hline Total laryngectomy (TL) & 55 & 68.75 \\
\hline Emergency tracheostomy (ET) & 7 & 8.75 \\
\hline Tracheostomy associated with other surgery & 10 & 12.50 \\
\hline ET followed by TL & 8 & 10.00 \\
\hline \multicolumn{3}{|l|}{ Prior contact with an ostomized patient } \\
\hline Yes & 34 & 42.50 \\
\hline No & 46 & 57.50 \\
\hline \multicolumn{3}{|l|}{ Preoperative nursing consultation } \\
\hline Yes & 39 & 48.75 \\
\hline No & 41 & 51.25 \\
\hline \multicolumn{3}{|l|}{ Informal caregiver } \\
\hline Yes & 56 & 70.00 \\
\hline No & 24 & 30.00 \\
\hline
\end{tabular}

Thus, the sample was mostly comprised of men, with a mean age of 60 years, who had basic education, and were retired. From a clinical perspective, most of them had undergone surgery at least 1 month ago, knew the diagnosis that led to surgery, had been submitted to surgical and permanent tracheostomy, mostly a total laryngectomy, and had no preoperative nursing consultation. It should be noted that most of them had no contact with tracheostomy patients before surgery and had an informal caregiver at home.

Data were processed and analyzed using SPSS (Statistical Package for the Social Sciences), version 20.0. Given the abnormal distribution of data, non-parametric statistical tests were used.

This study complied with all ethical assump- 
tions inherent to health research: permission was requested to the Ethics Committees of the health institutions involved, all potential participants were asked to give their informed consent for participation in this study; the participants' anonymity and data confidentiality were ensured, as well as their right to withdraw from the study at any time without prejudice associated with non-participation or withdrawal.

\section{Results}

As regards the level of self-care competence, the sample was partially competent in tracheostomy self-care (mean score $=4$ ) in all domains. Participants were more competent in the domains of Execution (mean score $=4.42$ ) and Knowledge (mean score $=4.40)$, while being less competent in Interpretation (mean score $=3.68$ ) and Decision-making (mean score $=3.96)$. On the other hand, and analyzing the results according to each outcome indicator, the sample was partially competent in all indicators, except for item 1 "knows what is a tracheostomy" and item 2 "knows the purpose of a tracheostomy" in the domain of knowledge, in which participants were fully competent (score $=5$ ).

The main results obtained on the level of tracheostomy self-care competence according to the variables are summarized in Table 2.

Thus, the results show that women had significantly higher mean scores in the domain Negotiation and Use of Health Resources (F) than men.

Employed participants had a higher competence mean score in the domain of Interpretation than unemployed people and those in other non-active professional situations.

There is also a positive, moderate to low, but significant correlation between the years of education and all domains of self-care competence, with the exception of the domain Execution (E).

Table 2

\section{Results of the sociodemographic variables}

\begin{tabular}{|c|c|c|c|c|c|c|c|c|}
\hline \multirow{2}{*}{\multicolumn{2}{|c|}{ Variable }} & \multicolumn{7}{|c|}{ Domains of tracheostomy self-care competence } \\
\hline & & \multirow{2}{*}{\multicolumn{2}{|c|}{$\begin{array}{c}\text { Knowledge } \\
\text { (A) } \\
M=4.43\end{array}$}} & \multirow{2}{*}{$\begin{array}{c}\begin{array}{c}\text { Self- } \\
\text { monitoring } \\
(\mathrm{B})\end{array} \\
\mathrm{M}=4.23\end{array}$} & \multirow{2}{*}{$\begin{array}{c}\begin{array}{c}\text { Interpretation } \\
(\mathrm{C})\end{array} \\
\mathrm{M}=3.68\end{array}$} & \multirow{2}{*}{$\begin{array}{c}\begin{array}{c}\text { Decision- } \\
\text { making } \\
(\mathrm{D})\end{array} \\
\mathrm{M}=3.93\end{array}$} & \multirow{2}{*}{$\begin{array}{c}\text { Execution } \\
\text { (E) } \\
M=4.42\end{array}$} & \multirow{2}{*}{$\begin{array}{l}\begin{array}{l}\text { Negotiation and Use } \\
\text { of Health Resources } \\
(\mathrm{F})\end{array} \\
\mathrm{M}=4.16\end{array}$} \\
\hline \multirow{3}{*}{$\frac{\vec{v}}{\vec{U}}$} & Male & & & & & & & \\
\hline & Female & & $\mathrm{M}=3.77$ & $M=4.70$ & $M=3.63$ & $M=4.83$ & - & $M=4.83$ \\
\hline & $\mathrm{U}$ & & ns & ns & ns & ns & ns & $8.5^{*}$ \\
\hline \multirow{5}{*}{ 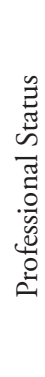 } & Employed & & $M=4.54$ & $M=4.40$ & $M=4.50$ & $M=4.67$ & - & $M=4.00$ \\
\hline & Unemployed & & $M=4.17$ & $M=4.17$ & $M=2.83$ & $\mathrm{M}=3.48$ & $M=4.09$ & $M=3.50$ \\
\hline & Retired & & $M=4.44$ & $M=4.28$ & $M=3.84$ & $M=4.07$ & $M=4.44$ & $M=4.20$ \\
\hline & Disabled & & $M=4.54$ & $M=4.20$ & $M=3.95$ & $M=4.07$ & - & $M=4.40$ \\
\hline & $\mathrm{H}$ & & ns & ns & $14.66^{* *}$ & ns & ns & ns \\
\hline & Education & $\mathrm{r}_{\mathrm{s}}$ & $0.32^{* *}$ & $0.29^{*}$ & $0.28 *$ & $0.32^{* *}$ & ns & $0.40^{\text {** }}$ \\
\hline
\end{tabular}

$\mathrm{M}=$ Mean; $\mathrm{H}=$ Kruskal-Wallis Test; $r s=$ Significance test of Spearman's correlation; $n s=$ non-significant. $(-)=$ Non-assessed test (empty group - constant variable). ${ }^{*} p<0.05 ;{ }^{* *} p<0.01$. 
The Spearman's correlation test showed no significant differences between the level of ostomy self-care competence and age.

With regard to clinical variables, the results obtained in this study are shown in Table 3.

The analysis of Table 3 reveals that individuals with a permanent ostomy had significantly higher competence mean scores in the domains Knowledge (A), Self-monitoring (B), Interpretation $(\mathrm{C})$, and Decision-making (D) than those with a temporary tracheostomy or who are unaware of its duration.

As regards the type of surgery, significant differences were found in the domains of Knowledge (A), Interpretation (C), and Decision-making (D). Thus, people who underwent an emergency tracheostomy showed lower competence mean scores in these domains. In contrast, people who had a total laryngecto- my showed higher self-care competence mean scores in the domain of Knowledge (A). In the domains of Interpretation (C) and Decision-making (D), patients who had an emergency tracheostomy followed by total laryngectomy had the highest mean scores.

Patients who had undergone surgery more than 1 month before had significantly higher levels of competence in all domains.

With regard to the health monitoring variables, the mean comparison showed no statistically significant differences between the level of ostomy self-care competence and the contact with ostomized patients before the surgery $(p>0.05)$. It also showed no statistically significant differences between attending or not a preoperative nursing consultation and the level of tracheostomy self-care competence $(p>0.05)$.

Table 3

Results on the clinical variables

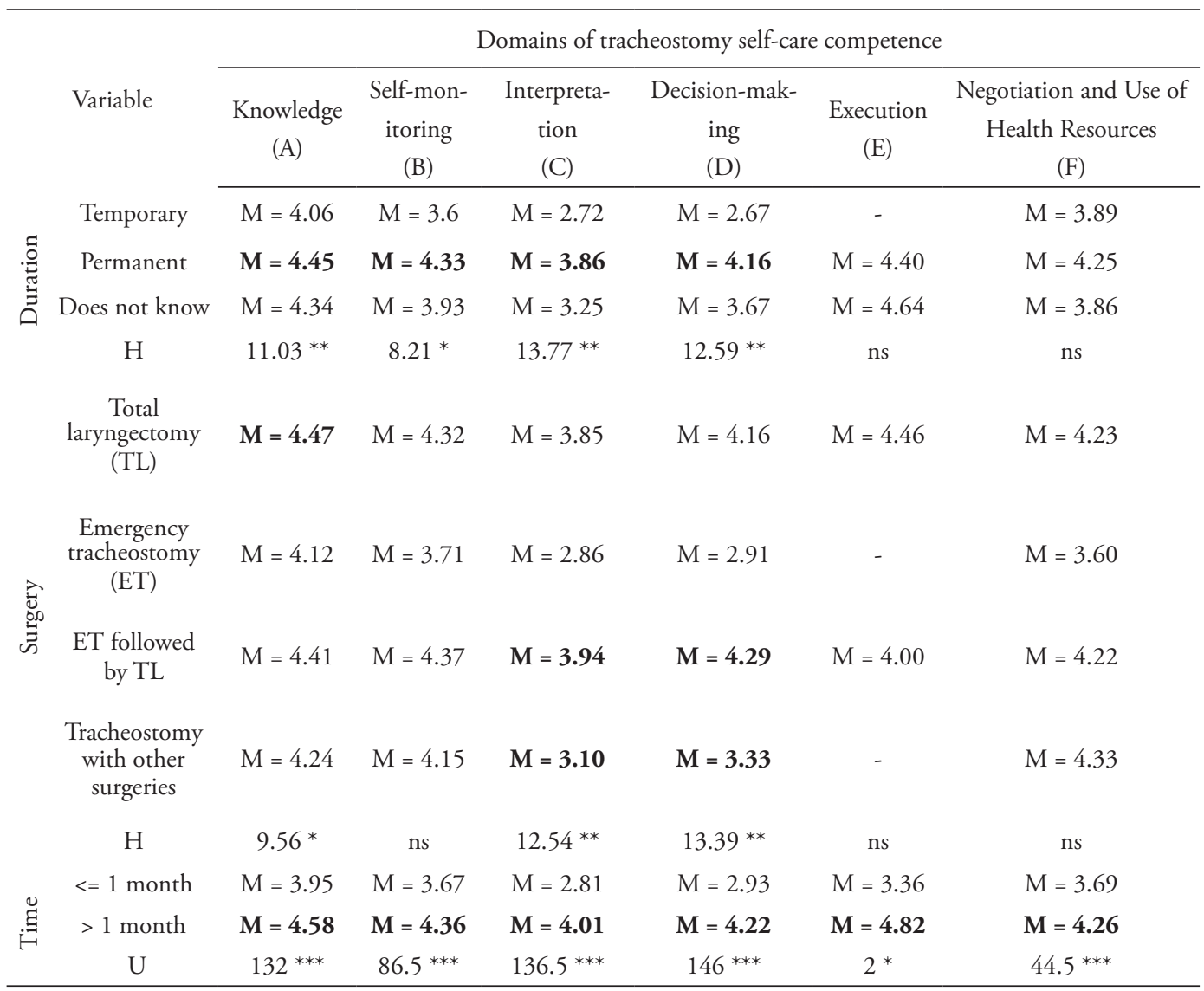

$\mathrm{M}=$ Mean; $\mathrm{H}=$ Kruskal-Wallis Test; $\mathrm{U}=$ Mann-Whitney's Test; $r s$ = Significance test of Spearman's correlation; $n s$ $=$ non-significant; $(-)=$ Non-assessed test (empty group - constant variable). ${ }^{*} p<0.05 ;{ }^{* *} p<0.01 ;{ }^{* * *} p<0.001$. 
Finally, the results obtained on the level of tracheostomy self-care competence according to the existence of informal caregivers are shown in Table 4.

In view of the above, people with a tracheos- tomy who have no informal caregiver seem to be significantly more competent in the domains of Knowledge (A), Self-monitoring (B), and Interpretation (C) than those with a informal caregiver.

Table 4

Results of the sample according to the existence of a informal caregiver

\begin{tabular}{|c|c|c|c|c|c|c|c|}
\hline & & \multicolumn{6}{|c|}{ Domains of tracheostomy self-care competence } \\
\hline \multicolumn{2}{|c|}{ Variable } & $\begin{array}{c}\text { Knowledge } \\
\text { (A) }\end{array}$ & $\begin{array}{l}\text { Self-monitoring } \\
\text { (B) }\end{array}$ & $\begin{array}{l}\text { Interpretation } \\
\text { (C) }\end{array}$ & $\begin{array}{l}\text { Decision-making } \\
\text { (D) }\end{array}$ & $\begin{array}{l}\text { Execution } \\
\text { (E) }\end{array}$ & $\begin{array}{c}\text { Negotiation and } \\
\text { Use of Health } \\
\text { Resources (F) }\end{array}$ \\
\hline \multirow{3}{*}{ 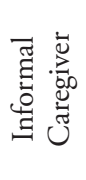 } & Yes & $M=4.33$ & $M=4.17$ & $M=3.53$ & $M=3.82$ & $M=4.10$ & $M=4.16$ \\
\hline & No & $M=4.58$ & $M=4.42$ & $M=4.03$ & $M=4.25$ & $M=4.98$ & $M=4.24$ \\
\hline & $\mathrm{U}$ & $406.5^{*}$ & $324^{*}$ & $446.5^{*}$ & ns & ns & ns \\
\hline
\end{tabular}

$U=$ Mann-Whitney's test. ${ }^{*} p<0.05$.

\section{Discussion}

The analysis on the level of tracheostomy selfcare competence according to the sociodemographic variables shows that women are more competent than men in seeking health services, particularly to obtain material, clarify doubts, or solve problems. This result may be related to the fact that women are more engaged in their health and that the female gender is one of the most commonly associated demographic characteristics with the use of health resources, even for preventive measures (Levorato, Mello, Silva, \& Nunes, 2014).

In addition, people with a higher level of education have a higher level of tracheostomy self-care competence, which may mean that these patients' intellectual resources are learning facilitators, leading them to seek more information (Perrenoud, as cited in Mitchell, 2004). In the same way, studies suggest an association between lower levels of education and fewer linguistic skills to question health professionals and critical-reflexive skills to assess health conditions, care delivery, and patient rights (Bellato et al., 2006). Thus, the results indicate that the years of education may be an intrinsic facilitating factor for the individual's development of ostomy self-care competence.

Significant differences were also found in the level of self-care competence in the domain of Interpretation according to the professional situation. Employed participants showed a higher mean self-care competence score than other participants. In line with these findings, Liu et al. (2016) also suggested that employed participants have better scores in functional capacity, self-confidence, and perceived quality of life, and that their active participation in work contributed to their adaptive process after an ostomy. Indeed, employed patients, due to their professional demands, are more likely to have a better psychological adjustment to the stoma and be more autonomous in care, because they will have to care for themselves in their workplace (Pereira et al., 2012).

The analysis of the clinical variables shows that people who know that their ostomy is permanent are more competent in the domains of Knowledge, Self-monitoring, Interpretation, and Decision-making than those who have a temporary ostomy or those who do not know how to answer this question. The existing literature on this topic (Recalla et al., 
2013) corroborates these results to the extent that it shows that people with a permanent ostomy tend to use confrontational strategies for solving problems, thus being usually more confident and adapting more easily to change. For this reason, they may develop their ostomy self-care skills faster and have a better perceived quality of life. On the other hand, this fact may also be associated with a greater involvement of the patient with a permanent ostomy since he/she is aware that it is a condition that will last forever (Campillo Martínez, 2015).

In addition, the results show that the type of surgery influences the level of self-care competence, since people who underwent an emergency tracheostomy have lower levels of self-care competence in the domains of Knowledge, Interpretation, and Decision-making. The fact that a person is or is not prepared for the ostomy and its consequences affects their self-care performance (Mota el al., 2015). In emergency tracheostomies, it is impossible to be prepared for surgery since it results from a sudden situation. For this reason, it is more difficult for them to accept the stoma, which will have a potential impact on the development of ostomy self-care competence (Thorpe, McArthur, \& Richardson, 2014; Mota et al., 2015). On the contrary, since a total laryngectomy is a planned surgery, the participant can be more prepared and potentially more ready to deal with change. The fact that people who have an emergency tracheostomy followed by total laryngectomy have higher levels of competence in Interpretation and Decision-making can be associated with their previous experience of having had a tracheostomy. This event can provide them with the opportunity to improve their ability to evaluate the stoma and its complications and, consequently, decide on the most effective care when it becomes a permanent ostomy.

Participants who had undergone surgery longer ago had higher levels of competence in all self-care domains. This result is consistent with the existing evidence that suggests that the duration of experience is a positive predictor of ostomized patients' acceptance and adaptation to the condition (Brown \& Randle, 2005; Richbourg, Thorpe, \& Rapp,
2007; RNAO, 2009, Mota et al., 2016). The repetition of care and the experience with the ostomy over time allow people to acquire greater self-care competence, thus becoming more independent (Thorpe et al., 2014; Lim et al., 2015; Mota et al., 2016).

The results also show that there are no statistically significant differences between the level of ostomy self-care competence and attending or not a preoperative nursing consultation. In this regard, the results found in the literature are contradictory. In the literature review performed, the preoperative information is a facilitating factor for the adaptation to the ostomy, because it helps reducing fear and anxiety and promotes confidence, knowledge, coping, and involvement in change (Richbourg et al., 2007; RNAO, 2009; Thorpe et al, 2014; Mota et al., 2015). The results may be related to the model used in preoperative nursing consultations which may not be adjusted to these patients' needs or focused on promoting autonomy. This would justify the development of another study with a larger and more representative sample closer to the moment of surgery so as to identify the influence of the preoperative nursing consultation in the development of ostomy self-care competence.

The prior contact with tracheostomy patients was also not significant to the expected results, which contradicts the results of other studies on this topic (Mota et al., 2015; Mota et al., 2016). In almost all cases reported, the contact was occasional and unintended, and did not include the sharing of opinions or experiences, which may explain the fact that its impact on the level of self-care competence was not clear.

It is also important to analyze the results on the existence, or not, of a informal caregiver and its influence on the level of tracheostomy self-care competence. Similarly to other studies, the obtained results suggest that the existence of a informal caregiver can lead to a lower involvement in self-care. The patient who knows that there is a competent relative willing to take responsibility for care may stop performing these tasks, and become dependent (Mota et al., 2016). On the contrary, people without support at home must become more involved, thus developing auton- 
omy, and, consequently, greater competence in ostomy self-care (Mota et al., 2016).

\section{Conclusion}

The acquisition of autonomy in ostomy self-care is essential for ostomized patients' adaptation to life with a stoma, prevention of complications, and promotion of health, well-being, and quality of life. Therefore, nurses should be aware of their role in empowering ostomized patients for physical, social, and psychological changes, as well as for self-care.

This study allowed identifying factors that condition the development of self-care competence in the person with a tracheostomy, which was one of the objectives set out. The confirmation of different levels of tracheostomy self-care competence according to gender, level of education, time elapsed since surgery, duration of the ostomy, type of surgery, and existence of an informal caregiver allowed concluding that there are conditioning factors for the development of self-care competence. The results of this study suggest that being a man, having a low level of education, having a temporary ostomy, having undergone an emergency surgery, and the existence a informal caregiver are factors that inhibit the development of tracheostomy self-care competence. In contrast, the time elapsed since surgery proved to be a facilitating factor for the development of ostomy self-care.

Thus, based on the results obtained on the conditioning factors for the development of self-care competence in the person with a tracheostomy, nurses are able to design more adjusted intervention plans that maximize their patients' therapeutic success. Understanding the influence of the sociodemographic, clinical, and health monitoring variables in the development of self-care competence in the person with a tracheostomy is essential for the success of the nurse's therapeutic process aimed at achieving a healthy transition to life with a tracheostomy. Therefore, this study contributed to the early identification of highly vulnerable people in terms of the acquisition of self-care competence, who will potentially require a closer and continuous follow-up by the nursing team.

Indeed, the transition to life with an ostomy is complex, subjective, and influenced by several complicating factors. The identification of these conditioning factors will allow nurses to implement their interventions more effectively and efficiently, in order to help their patients to develop self-care skills and lead a more autonomous and healthier life.

Given the fact that this topic is still understudied, this study contributed to better understand this population group. However, it should be noted that this study had some limitations: the size of the sample, which should be larger to achieve more accurate results, particularly in some of the analyzed subgroups which were less represented in the sample, such as female and employed patients; the use of a nonprobability sampling technique, which conditions the representativeness of the population and, as a result, the generalization of the results; and, finally, the fact that data were only collected in two institutions from the north region of Portugal, which results in a narrow demographic representation. Therefore, further studies should be conducted with a larger sample to confirm these results and generalize them to the population with more confidence, as well as to clarify, in particular, the influence of the health monitoring variables in the development of self-care competence, since the results of this study are not in line with the evidence found. This article derived from the first author's Master's thesis entitled Development of the self-care competence in the person with a tracheostomy (Desenvolvimento da competência de autocuidado na pessoa com ostomia de ventilação).

\section{References}

Bellato, R., Pereira, W., Maruyama, A., \& Oliveira, P. (2006). A convergência cuidado-educação-politicidade: Um desafio a ser enfrentado pelos profissionais na garantia aos direitos à saúde das pessoas portadoras de estomias. Texto \& Contexto Enfermagem, 15(2), 334-342. doi:10.1590/S010407072006000200019

Brown, H., \& Randle, J. (2005). Living with a stoma: A review of the literature. Journal of Cli- 
nical Nursing, 14(1), 74-81. doi:10.1111/j. 1365-2702.2004.00945.x

Campillo Martinez, J. (2015). Estudio "Stoma Life Calidad de vida en los pacientes ostomizados un año despues de la cirugía. Metas Enfermagem, 18(8), 25-31.

Guerreiro, M., Silva, A., Botelho, M., Leitão, O., Castro-Caldas, A., \& Garcia, C. (1994). Adaptação à população portuguesa da traduçáo do Mini Mental State Examination. Revista Portuguesa de Neurologia, 1(9), 9-10.

Levorato, C., Mello, L., Silva, A., \& Nunes, A. (2014). Fatores associados à procura por serviços de saúde numa perspetiva relacional de género. Ciência e Saúde Coletiva,19(4), 1263-1272. doi:10.1590/141381232014194.01242013

Lim, S., Chan, S., \& He, H. (2015). Patients experiences of performing self-care of stomas in the initial postoperative period. Cancer Nursing, 38(3), 185193. doi:10.1097/NCC.0000000000000158

Liu, C., Ren, H., Li, X., Dai, Y., Liu, L., Ma, L., He, Q., \& Li, X. (2016). Predictors of quality of life of bladder cancer patients with ileal conduit: A cross sectional survey. European Journal of Oncology Nursing, 21, 168-173. doi:10.1016/j.ejon.2015.09.008

Maasland, D., Brandt, P., Kremer, B., Goldbohm, R., \& Schouten, L. (2014). Alcohol consumption, cigarette smoking and the risk of subtypes of head-neck cancer: Results from the Netherlands cohort study. BMC Cancer, 14(187), 2-14. doi:10.1186/14712407-14-187

Mitchel, L. (2004). Gestão de pessoas por competências no ambiente aulaNet (Master's dissertation). Universidade Católica do Rio de Janeiro, Departamento de Informática de Pontifícia, Brasil. Retrieved from http://groupware.les.inf.puc-rio.br/public/papers/ dissertacaoluis.pdf

Mota, M., Gomes, G., Petuco, V., Heck, R., Barros, E., \& Gomes, V. (2015). Facilitators of the transition process for the self-care of the person with stoma: Subsidies for Nursing. Revista da Escola de Enfermagem da USP, 49(1), 80-86. doi:10.1590/S0080623420150000100011

Mota, M., Gomes, G., Silva, C., Gomes, V., Pelzer, M., \& Barros, E. (2016). Autocuidado: Uma estratégia para a qualidade de vida da pessoa com estomia. $R e-$ vista de Investigação em Enfermagem, 18(1), 63-78. doi:10.11144/Javeriana.ie18-1.aeqv

O'Connor, G. (2005). Teaching stoma-management skills: The importance of self-care. British Journal of Nursing, 14(6), 320-324. doi:10.12968/ bjon.2005.14.6.17800

Orem, D. (1995). Nursing: Concepts of practice ( $5^{\text {th }} \mathrm{ed}$.). New York, USA: Mosby.

Parker, V., Shylan, G., Archer, W., McMullen, P., Morrison, J., \& Austin, N. (2007). Trends and challenges in the management of tracheostomy in older people: The need for a multidisciplinary team approach. Contemporary Nurse, 26(2), 177-183. doi:10.5555/conu.2007.26.2.177

Pereira, A., Cesarino, C., Martins, M., Pinto, M., \& Netinho, J. (2012). Associação dos fatores sociodemográficos e clínicos à qualidade de vida dos estomizados. Revista Latino-Americana de Enfermagem, 20(1), 1-8. doi:10.1590/S010411692012000100013

Queirós, S., Santos, C., Brito, A., \& Pinto, I. (2015). Construção do formulário de avaliação da competência de autocuidado na pessoa com ostomia de ventilação. Revista de Enfermagem Referência, 4(7), 51-60. doi:10.12707/RIV15010

Recalla, S., English, K., Nazarali, R., Mayo, S., Miller, D., \& Gray, M. (2013). Ostomy care and management: A systematic review. Journal of Wound, Ostomy and Continence Nursing, 40(5), 489-500. doi: https:// dx.doi.org/10.1097/WON.0b013e3182a219a1

Registered Nurses' Association of Ontario. (2009). Ostomy care and management: Clinical best practice guidelines. Toronto, Canada: Author.

Richbourg, L., Thorpe, J., \& Rapp, C. (2007). Difficulties experienced by the ostomate after hospital discharge. Journal of Wound, Ostomy \& Continence Nursing, 34(1), 70-79.

Thorpe, G., McArthur, M., \& Richardson, B. (2014). Healthcare experiences of patients following faecal output stoma-forming surgery: A qualitative exploration. International Journal of Nursing Studies, 51(3), 379-389. doi: https://dx.doi.org/10.1016/j. ijnurstu.2013.06.014

Walker, C. \& Lachman, V. (2013). Gaps in the discharge process for patients with an ostomy: An ethical perspective. Medsurg Nursing, 22(1), 61-64. 